\title{
Evaluation of Agronomic and Physiological Characteristics of Ten Castor Bean Plant Accessions in Ogbomoso, Nigeria
}

\author{
Omotoso O. L. Lawal, B. A. ${ }^{*} \quad$ Akanbi, W.B. Ilupeju, E. A. \\ Department of Crop Production and Soil Science, Ladoke Akintola University of Technology, Ogbomoso, Oyo \\ State, Nigeria
}

\begin{abstract}
In spite of numerous industrial benefit of castor plant (Ricinus communis L.), its production is hindered due to lack of adequate agronomic practices. Field experiments were conducted at the Teaching and Research Farm, Ladoke Akintola University of Technology, Ogbomoso, Nigeria during 2014 and 2015 cropping seasons to evaluate the performance of ten accessions of castor plant. The treatments consisted of nine improved accessions of castor plant and a local variety. In each year, the 10 treatments were laid out in completely randomize block design and replicated three times. Data were collected on growth, seed yield and yield attributes parameters. Data collected in 2014 and 2015 were pooled and subjected to analysis of variance while means were separated using Least Significant Difference at 5\% probability level. Growth, yield and yield attributes parameters of castor plant accessions were significantly influenced $(\mathrm{p} \leq 0.05)$. NCRICAS041 produced the tallest plant $(190.0 \mathrm{~cm})$ at harvest which was significantly taller than others. The highest mean number of capsules per raceme (150.33) produced by NCRICAS056 was significantly higher than others. NCRICAS056 produced the highest seed yield $(1,919 \mathrm{~kg} / \mathrm{ha})$ while NCRICAS057 gave the least $(1,047 \mathrm{~kg} / \mathrm{ha})$. The results of accessions seed yield attributes did not followed any specific other. In conclusion, variability among the accessions in growth and seed yield were apparent. Accessions NCRICAS041 and NCRICAS056 performed better than the locally sourced CASGPMAN. They are therefore recommended for the study area.
\end{abstract}

Keywords: Castor, Accessions, Growth parameter, Seed, Seed attributes,

DOI: $10.7176 / \mathrm{JNSR} / 9-18-03$

Publication date:September $30^{\text {th }} 2019$

\section{INTRODUCTION}

Castor plant, (Ricinus communis L.) is widespread throughout the tropical regions. It is a crop grown for the production of oil by industries (Uvah, 1991). In Nigeria, castor plant is present as a wild plant and has different name according to the area where it is found. It is called 'Lara' by the Yoruba, 'Zurma' by the Hausa and 'Kwolakwola' by the Kanuris while the Igbos refers to it as Ogilisi (Oluwole, et al., 2016). Castor plant is cultivated in many countries among which is India, China, Brazil, and Madagascar mainly for industrial purposes (Tchuenteu et al., 2013). In 2008 Sujatha et al, reported that there is a steady increase in demand for castor oil in the world market which brings about the opportunity to improve and increase castor production. In this respect, Reddy and Matcha (2010) suggested that castor can become a cash crop in modern agriculture. Castor seeds varied in size, colour, oil and ricinus content; it could be white big, black big, grey medium and grey small with a range of 40 to $60 \%$ oil (Olaoye, 2000). The oil is colorless to very pale yellow liquid with mild or no odor or taste (Msaakpa and Obasi, 2014). Among vegetable oils, castor oil is distinguished by its higher content of ricinoleic acid than any other vegetable oil (Chakrabarti and Rafiq, 2008), and very low solidification point which makes it a useful raw material for industries. Castor oil is traditionally used as medicinal ointment (Olaniyan 2010), has many industrial uses which includes manufacturing of lubricants, hydraulic and brake fluids, paints, dyes, coating, inks, cold resistant, plastics, varnishes, lacquers, oil clothes, linoleum grease, waxes, polishes, nylon, pharmaceuticals and perfumes (Olaoye and Busari 2017). The oil has so many advantages over petroleum base oils, especially at high and low temperatures due to its high boiling and low melting points. Castor oil can also be used for reducing greenhouse gases as the oil produces relatively high crop yield with relatively low input (Demirbas, 2007).

Performance of Castor plants, like any other crop could vary with many factors including genotype, environment, cultural and harvesting practices (Akande et al., 2012; Adebayo et al., 2013). Also, high temperatures above $35^{\circ} \mathrm{C}$ and water stress during the flowering and oil formation can reduce the seed oil content (Yusuf et al., 2015). Many studies have been initiated in this direction to introduce and study the adaptability of castor bean in different agro ecological zones (Tchuenteu et al., 2013). Castor plant has been demonstrated to grow well in little shade on soil rich in organic manure, well drained and possessing neutral pH (Weiss, 2000). In Nigeria there is little information about its agronomic practices despite the fact that the plant abound almost everywhere in the wild. With the view to exploring the possibility of castor oil as an alternative cash crop in Nigeria, there is the need to ascertain the growth attribute of the available accessions in the southern guinea savannah regions, where in Nigeria seems to be a favorable agricultural zone for castor production. However, there is scarcity of information on the performance of the crop under this climate, hence, the present research therefore focus on the evaluation of agronomic and physiological characteristics of ten castor plant accessions in Ogbomoso, Oyo State, Nigeria. 


\section{MATERIALS AND METHODS}

The studies were conducted during July and December in 2015 and repeated at the same period in 2016 at the Teaching and Research Farm, Ladoke Akintola University of Technology, Ogbomoso. Nigeria. Ogbomoso lies on latitude $8^{\circ} 10^{1} \mathrm{~N}$ and longitude $4^{\circ} 10^{1} \mathrm{E}$ with elevation of $390 \mathrm{~m}$ above sea level. The area had a bimodal rainfall pattern between April to July and September to November. The mean daily maximum and minimum temperatures were about 33 and $20^{\circ} \mathrm{C}$ respectively. Mixed cropping is the major cropping pattern in the area. Prominent weed species on the site includes Euphorbia heterophylla, Amaranthus spinosis, Commelina sp, Imperata cylindrica and Tithonia diversifolia. The soil of this experimental site is classified as Olorunda series (Smyth and Montgomery, 1962) which was derived from fine-grained gnesis. The soil is moderately drained, ferruginous with sandy loam texture. The treatment is the 10 accessions of castor plant. Five of which are NCRI lines (NCR1CAS007, NCR1CAS041, NCR1CAS056, NCR1CAS057, NCR1CAS081) developed by National Cereals Research Institute (NCRI), Badegi, Niger State, Nigeria, four are IAR lines (IARCAS001, IARCAS011, IARCAS021, IARCAS023) obtained from Institute of Agricultural Research (IAR), Zaria Nigeria while the tenth accession, CASGPMAN was a local accession obtained from local market at Iluju, Orire Local Government area, Ogbomoso. The local one was used as a check while other accessions are for adaptability trial across different Agro-ecological zones in Nigeria. Each treatment plot measured 10.5 by $4.5 \mathrm{~m}$, planted at 1.5 by $1.5 \mathrm{~m}$, giving a plant population of 4,444 per hectare. Each treatment plot has three replicates giving a total of 30 treatment plots. Planting was done after land preparation by placing three seeds per hole; this was thinned to one plant per hole together with supplying at 2 weeks after planting. NPK 20:10:10 fertilizer was basally applied at the rate of $600 \mathrm{~kg} / \mathrm{ha}$ at one month after planting. This is equivalent to 120,60 , and $60 \mathrm{~kg} \mathrm{~N}, \mathrm{P}_{2} \mathrm{O}_{5} \mathrm{~K}_{2} \mathrm{O}$ respectively. However, weed and pest were controlled using pre emergence herbicide, Atrazine at the rate of $2.5 \mathrm{~kg}$ per hectare, by mixing $200 \mathrm{~g}$ in 15 litre capacity sprayer after which two supplemental manual hoeing were carried out while insect pests were controlled by spraying Cypermetrin at the rate of $40 \mathrm{ml} / 20$ liter water monthly and was done three times. Data were collected on growth, reproductive, seed and seed yield parameters. Five plants were tagged per plot. The tagged plants were assessed and their means were recorded for the following parameters: stem height at maturity, number of branches per plant, number of nodes per plant, number of racemes per branch, number of capsules per raceme, mean raceme weight, number of seeds per raceme, seed shelling percentage, weight of seed per raceme, 100 seeds weight $(\mathrm{g})$ and seed yield $(\mathrm{kg} / \mathrm{ha})$. Data collected were analysed using analysis of variance while means were separated with Least Significant Difference at $5 \%$ probability level.

\section{RESULTS}

All the parameters were significantly influenced $(\mathrm{p} \leq 0.05)$ by the accession type. The highest height at harvest $(190.00 \mathrm{~cm})$ produced by NCRICAS041 was significantly taller than other accessions while the shortest height $(73.67 \mathrm{~cm})$ obtained from NCRICAS057 was also significantly shorter than other accessions (Table 1). Mean number of branches was also significantly influenced by accession type. The highest mean number of branches per plant which was significantly higher than others was produced by NCRICAS041 (8.67), while the least, (2.33) produced by NCRICAS 057 was not statistically different compared with 2.67 produced by each of NCRICAS007 and IARCAS021 respectively (Table 1). In respect of number of nodes per plant, IARCAS011 produced the highest (14.67) which was significantly different compared with 12.67 produced by each of IARCAS 001 and IARCAS021 respectively. In the case of reproductive parameters, all the measured parameters were also significantly influenced by accession type (Table 2). IARCAS011 and local accession (CASGPMAN) produced the highest mean number of racemes per branch (6.33) which was significantly higher than 4.33 mean value produced by NCRICAS041, IARCAS021 and IARCAS023 (Table 2). NCRICAS057 produced the least number of racemes per plant.

Furthermore, NCRICAS accessions produced more capsules per raceme compared with IARCAS and the local accession. NCRICAS056 produced the highest (150.33) which was significantly higher than number of capsules by others while the least, 30.00 produced by IARCAS001 was statistically similar compared with 33.00 harvested from IARCAS023. The highest mean raceme weight $(113.33 \mathrm{~g})$ harvested from IARCAS001 was followed by NCRICAS056 $(102.00 \mathrm{~g})$, while least, $29.00 \mathrm{~g}$ was produced by NCRICAS057. IARCAS011 and NCRICAS007 had similar mean raceme weight (41.01 and $39.00 \mathrm{~g}$ respectively). Seed production of tried accessions was presented in Figure 1. NCRICAS056 produced 1,919 kg seed per hectare which was significantly higher than produce from others. The seed production did not follow any specific order within the source (NCRI and IAR). Least seed produce was obtained from NCRICAS057 $(1,047 \mathrm{~kg} / \mathrm{ha})$ which was significantly lesser than 1,130 and $1,184 \mathrm{~kg} / \mathrm{ha}$ produced by IARCAS023 and NCRICAS007 respectively. Seed yield attributes are presented in Table 3. NCRICAS056 produced the highest number of seeds per raceme (453) which was significantly higher than others while IARCASO23 produced the least (81.33). The shelling percentage did not follow any specific order within the source, 91.67 shelling percentage was obtained in respect of NCRICAS041 which was not significantly higher than $90.33 \%$ obtained from NCRICAS056 while the least $(76.33 \%)$ was recorded from IARCAS023. The accessions have similar response in respect of weight of seeds per raceme and 
100 seed weight. IARCAS001 has highest value in respect of the two; it however produced less number of seeds per raceme (Table 3).

\section{DISCUSSION}

Enormous variability was observed in castor accessions tested for agronomic attributes. Generally, the NCRICAS accessions where taller than IARCAS. The local accession CASGPMAN is of medium height. The growth response exhibited by the accessions could be attributed to favorable environmental conditions as reported by Udoh and Abu (2016). They however noted that the perennial growth habit and height attained by castor plants limit mechanical harvest because the plant grows very tall when the environmental conditions are desirable. In the report of Udoh et al. (2016), the performance of castor plant was attributed to ability to compete better for resources. In respect of seed yield and its attributes, there was significant variation among the accessions tried. Generally, the NCRICAS lines produced more seeds compared with IARCAS ones. However, despite the fact that the IARCAS lines produced less number of seeds per raceme, their seed weights were comparably higher. High variation in seed weight may likely be attributed to presence of immature seeds, damaged or unfilled seed as reported by Adu-Kwarteng et al., (2003). However, all the factors so noted were avoided in this trial. The shelling percentages also did not follow any specific order; some of the NCRICAS lines had higher percentages compared with IARCAS lines. Reports of higher seed weight from hybrids of castor plants (Wang et al., (2010); GoytiaJiménez et al., (2011) and Acosta-Navarrete et al., (2017)) agreed with the observations that IARCAS and NCRICAS lines produced better 100 seeds weight compared with the local accession.

\section{CONCLUSION}

It is evident that the ten accessions tested exhibited good variability to the tested traits. However, NCRICAS056 that produced significantly higher seed yield was therefore recommended for the trial location Guinea Savanna zone of south west, Nigeria for economic returns.

\section{REFERENCES}

Olaoye, J. O. and Busari, R. A. (2017). Optimization of Mechanical Expression of Castor Seeds Oil (Ricinus communis) Using Response Surface Methodology. Arid Zone Journal of Engineering, Technology and Environment 13(6): 878-887.

Tchuenteu, T. J., Megueni, C. and Njintang, Y. N. (2013). A study of the variability for grain and oil yield and yield related traits of castor beans accessions in two savannah agroecological zones of Cameroon. International Journal of Bioscences 3(8): 251-263.

Uvah, I.I., Ogunbile, A.O., and Ahmed, B. (1991). Efficiency of some insecticides for Control of storage insects of cowpea, maize and sorghum under farmers' storage conditions. National Farm System Research Network pp. 101-108.

Msaakpa, T. S. and Obasi, M. O (2014) Correlated Studies between Growth and Yield Characters of Castor Bean (Ricinus communis L.) International Journal of Scientific and Research 4(7): 2250-3153

Reddy, K.R., and Matcha, S.K. (2010). Quantifying nitrogen effects of castor bean (Ricinus communis L.) development, growth, and photosynthesis. Industrial Crops and Products 31: 185-191.

Chakrabarti, M.H., and Rafiq, A. (2008). Transesterification Studies on Castor Oil as a First Step Towards its Use in Biodiesel Production. Pakistan Journal Botany 40(3): 1153-1157.

Olaniyan, A.M. (2010). Effect of Extraction Conditions on the Yield and Quality of Oil from Castor Bean. Journal of Cereals and Oilseeds 1 (2): 24-33

Adebayo Tajudeen Bale, Rofiat Tosin Adebayo, R. T., Damilola Tope Ogundele, Victoria Tosin Bodunde 4 (2013) Fatty Acid Composition and Physicochemical Properties of Casto (Ricinus Communis L.) seeds obtain from Malete, Moro Local Government Area, Kwara State, Nigeria. Chemistry and Materials Research 3(12): 1113.

Akande, T. O., A. A Odunsi, O. S. Olabode and T. K. Ojediran (2012) Physical and Nutrient Characterisation of Raw and Processed Castor (Ricinus communis L.) Seeds in Nigeria. World Journal of Agricultural Sciences 8(1): 89-95.

Yusuf, A.K., P.A.P. Mamza, A.S. Ahmed and U. Agunwa (2015) Extraction and Characterization of castor seed oil from wild Ricinus communis LINN. International Journal of Science, Environment and Technology 4(5): $1392-1404$.

Acosta-Navarrete, M. S., J. E. Botello-Álvarez, M. Hernández-Martínez, J. M. Barrón- Adame, J. QuintanillaDomínguez, G. Gonzalez-Alatorre, S. Montes-Hernández and J. Quintanilla-Domínguez (2017). Variability evaluation of castor seeds (Ricinus communis) by multivariate analysis of local accessions from Mexico, African Journal of Agricultural Research 12(29) 2388-2397.

Wang, M. L., Morris, J. B., Pinnow, D. L., Davis, J., Raymer, P., and Pederson, G. A. (2010). A survey of the castor oil content, seed weight and seed-coat colour on the United States Department of Agriculture 
germplasm collection. Plant Genetic Resources 8(3): 229-231.

Goytia-Jiménez M. A., Gallegos-Goytia C. H., Núñez-Colín C. A. (2011). Relationship among climatic variables with the morphology and oil content of castor oil plant (Ricinus communis L.) seeds from Chiapas. Revista Chapingo Serie Ciencias Forestales y del Ambiente 17(1):41-48.

Adu-Kwarteng, E., Ellis W.O., Odun, I. and Manful J.T. (2003). Rice grain quality: a comparison of local varieties with new varieties under study in Ghana. Food Control 14(7): 507-514.

Udoh, O. E. and Abu, N. E. (2016). Phenotypic variability in Nigerian castor (Ricinus communis L.) accessions. African Journal of Agricultural Research 11(42): 4222-4232

Demirbas, A. (2007). Importance of biodiesel as transportation fuel. Energy Policy 35(9): 4661- 4670

Olaoye J. O, (2000). Some physical properties of castor seed relevant to design of processing equipment. Journal of agricultural Engineering research 77, $113-118$.

Oluwole, F. A., Aviara, N. A. Umar, B. and Abdulrahim, A. T. (2016). Assessment of Physical Properties of Castor Seeds with Variety. Annals of Borno 26: 85-94

Weiss, E. A. (2000). Castor. In Oilseed Crops, $2^{\text {nd }}$ Edition, Blackwell Scientific Ltd., Oxford, 13-52.

Smyth, A. J. and Montgomery, R. F. (1962): Soils and Land Use in Central Western Nigeria. Ministry of Agriculture and Natural Resources. 265pp

Udoh, O.E., Abu, N.E., Ugwueze, C. and Ebeifenadi, U.C. (2016): Variations in seed traits of

castor (Ricinus communis) accessions collected from Enugu State, Nigeria. Journal of Tropical Agriculture, Food, Environment and Extension (15)1: 6-10

Sujatha, M., Reddy, T.P., and Mahasi, M.J. (2008). Role of biotechnological interventions in the improvement of castor (Ricinus communis L.) and Jatropha curcas L. Biotechnological Advances 26(5): 424-435.

Table1: Effect of accession type on growth parameters of castor plant in Ogbomoso

\begin{tabular}{lccc}
\hline Accession & $\begin{array}{c}\text { Height at harvest } \\
(\mathrm{cm})\end{array}$ & $\begin{array}{c}\text { Number of branches/plant } \\
\text { NCRICAS007 }\end{array}$ & Number of nodes/plant \\
NCRICAS041 & $120.00 \mathrm{f}$ & $2.67 \mathrm{~d}$ & $10.00 \mathrm{c}$ \\
NCRICAS056 & $190.00 \mathrm{a}$ & $8.67 \mathrm{a}$ & $6.67 \mathrm{~d}$ \\
NCRICAS057 & $171.33 \mathrm{~b}$ & $5.67 \mathrm{~b}$ & $12.33 \mathrm{~b}$ \\
NCRICAS081 & $73.67 \mathrm{~h}$ & $2.33 \mathrm{~d}$ & $6.33 \mathrm{~d}$ \\
IARCAS001 & $140.33 \mathrm{~d}$ & $4.33 \mathrm{c}$ & $10.33 \mathrm{c}$ \\
IARCAS011 & $170.00 \mathrm{~b}$ & $4.67 \mathrm{bc}$ & $12.67 \mathrm{~b}$ \\
IARCAS021 & $150.33 \mathrm{c}$ & $5.33 \mathrm{bc}$ & $14.67 \mathrm{a}$ \\
IARCAS023 & $111.33 \mathrm{~g}$ & $2.67 \mathrm{~d}$ & $12.67 \mathrm{~b}$ \\
CASGPMAN & $105.00 \mathrm{~g}$ & $4.46 \mathrm{bc}$ & $8.67 \mathrm{c}$ \\
\hline
\end{tabular}

Mean along the column with the same letter(s) are not significantly different (LSD0.05)

Table 2: Effects of accession type on reproductive parameters of castor plant in Ogbomoso

\begin{tabular}{lccc}
\hline Accession & $\begin{array}{c}\text { Number of racemes/branch } \\
\text { Number of } \\
\text { capsules/raceme }\end{array}$ & $\begin{array}{c}\text { Mean raceme weight } \\
(\mathrm{g})\end{array}$ \\
\hline NCRICAS041 & $2.67 \mathrm{c} 007$ & $61.00 \mathrm{ef}$ & $39.00 \mathrm{~h}$ \\
NCRICAS056 & $4.33 \mathrm{~b}$ & $130.00 \mathrm{~b}$ & $50.00 \mathrm{f}$ \\
NCRICAS057 & $2.00 \mathrm{~cd}$ & $150.33 \mathrm{a}$ & $102.00 \mathrm{~b}$ \\
NCRICAS081 & $1.67 \mathrm{~d}$ & $93.00 \mathrm{c}$ & $29.00 \mathrm{i}$ \\
IARCAS001 & $4.00 \mathrm{~b}$ & $66.33 \mathrm{e}$ & $89.33 \mathrm{~d}$ \\
IARCAS011 & $3.67 \mathrm{~b}$ & $30.00 \mathrm{~g}$ & $113.33 \mathrm{a}$ \\
IARCAS021 & $6.33 \mathrm{a}$ & $59.33 \mathrm{f}$ & $41.01 \mathrm{~h}$ \\
IARCAS023 & $4.33 \mathrm{~b}$ & $76.33 \mathrm{~d}$ & $97.00 \mathrm{c}$ \\
CASGPMAN & $4.33 \mathrm{~b}$ & $33.00 \mathrm{~g}$ & $46.00 \mathrm{~g}$ \\
\hline
\end{tabular}

Mean along the column with the same letter(s) are not significantly different (LSD 0.05) 
Table 3: Effect of accession type on seed yield and yield parameters of castor plant in Ogbomoso

\begin{tabular}{ccclc}
\hline Accession & Number of seeds/raceme & Shelling $(\%)$ & $\begin{array}{l}\text { Weight of seed/raceme } \\
(\mathrm{g})\end{array}$ & 100 seeds weight $(\mathrm{g})$ \\
\hline NCRICAS007 & $186.00 \mathrm{~d}$ & $82.00 \mathrm{e}$ & $29.33 \mathrm{i}$ & $18.67 \mathrm{~g}$ \\
NCRICAS041 & $237.33 \mathrm{~b}$ & $91.67 \mathrm{a}$ & $42.00 \mathrm{f}$ & $18.53 \mathrm{~g}$ \\
NCRICAS056 & $453.00 \mathrm{a}$ & $90.33 \mathrm{ab}$ & $82.00 \mathrm{~b}$ & $19.00 \mathrm{~g}$ \\
NCRICAS057 & $235.00 \mathrm{c}$ & $82.67 \mathrm{de}$ & $21.00 \mathrm{j}$ & $10.33 \mathrm{~h}$ \\
NCRICAS081 & $131.00 \mathrm{~h}$ & $82.00 \mathrm{e}$ & $66.67 \mathrm{~d}$ & $48.33 \mathrm{~b}$ \\
IARCAS001 & $85.67 \mathrm{i}$ & $85.33 \mathrm{c}$ & $91.00 \mathrm{a}$ & $87.00 \mathrm{a}$ \\
IARCAS011 & $145.33 \mathrm{~g}$ & $89.00 \mathrm{~b}$ & $35.00 \mathrm{~g}$ & $23.33 \mathrm{f}$ \\
IARCAS021 & $180.00 \mathrm{e}$ & $84.33 \mathrm{~cd}$ & $75.33 \mathrm{c}$ & $43.00 \mathrm{c}$ \\
IARCAS023 & $81.33 \mathrm{j}$ & $76.33 \mathrm{~g}$ & $32.00 \mathrm{~h}$ & $39.33 \mathrm{~d}$ \\
CASGPMAN & $151.67 \mathrm{f}$ & $80.10 \mathrm{f}$ & $48.00 \mathrm{e}$ & $34.00 \mathrm{e}$ \\
\hline
\end{tabular}

Mean along the column with the same letter (s) are not significantly different

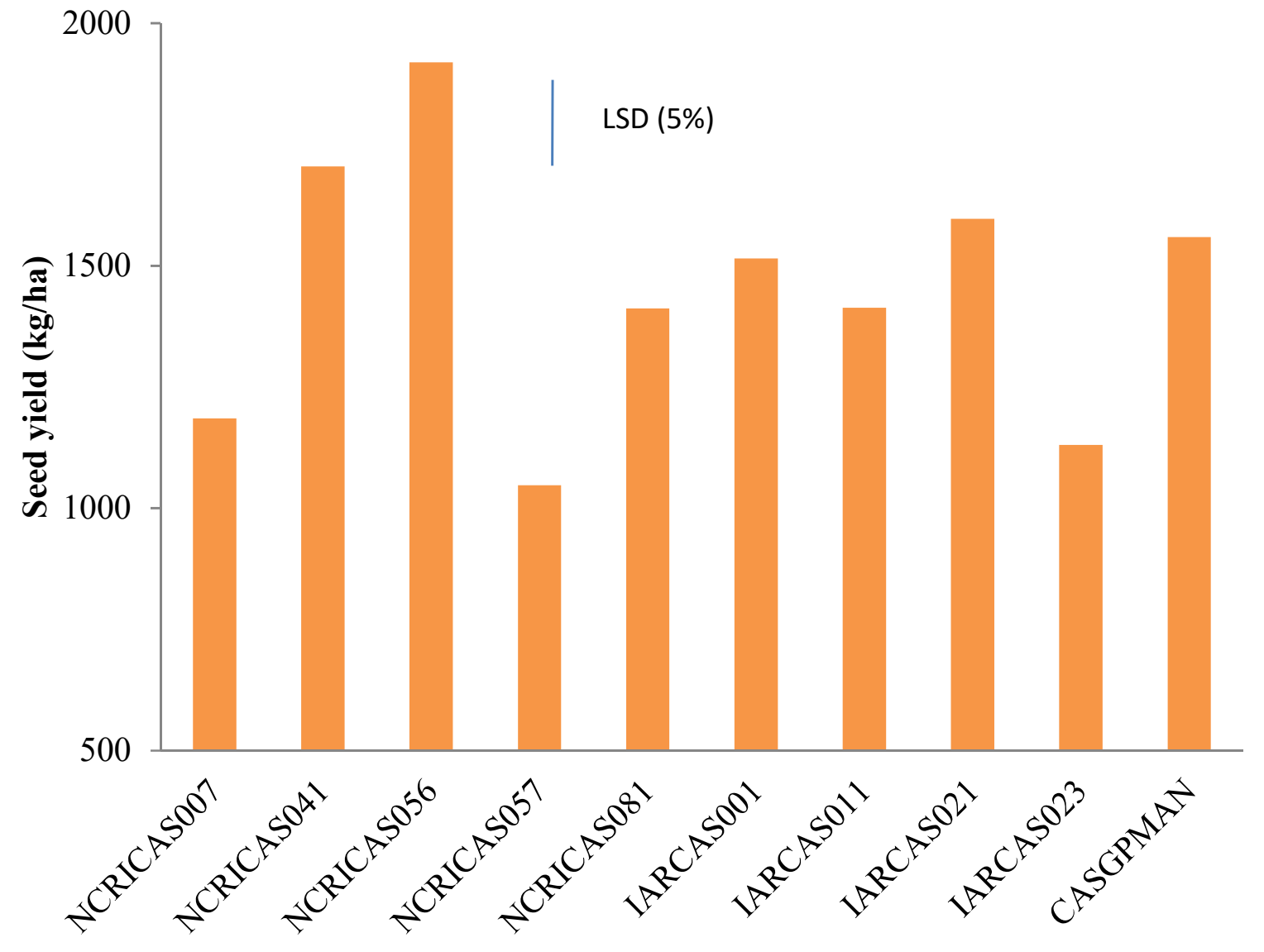

Accession

Figure 1: Effects of accession type on seed yield of castor plant in Ogbomoso Note: The bar represents Least Significant Difference value at 5\% probability 